\title{
弗素の蒾牙に対する作用に就いての実験的研究 続報＼cjkstart象牙質変化に就いての電子顯微鏡的検索
}

\author{
等 田賢 三 \\ 北海道大学医学部薬理学教室（主任 真崎教授）
}

\section{Studies of the Effect of Fluorine on Rabbit Dentin by Electron Microscopy}

\author{
Kenzo Kubota \\ From the Department of Pharmacology, Faculty of Medicine, \\ Hokkaido University (Prof. T. Masaki)
}

As already reported, the intravenous injection of fluoride solution causes the formation of a characteristic dentin layer in rabbits. But it has been not found the definite mechanism on this and then the author investigated this question by electron microscopy.

Visible changes were recognized when the dentin was etched with weak acid, therefore the detailed structures of the normal and decalcified dentin has been able to proved in electron micrographs.

The fluorine dentin layer has been observated as the decreasing region of acid solubility under the light microscope but revealed nothing by electron microscope. It is believed this reason that the decalcified surface structure of dentin is not different from the normal structure. Namely it is not indicated the fluoride deposits in the dentin fluorine layer.

In future it is advisable to differentiate the crystalline composition of the fluorine layer and the normal layer by electron or X-ray diffraction.

\footnotetext{
緒 言

弗素化された雪牙硬組織が酸に対する溶解性を 減少することは既に多くの 実験報告 ${ }^{1-9)}$ の指摘す る処で岗り，その出現機序に関しては弗化カルシ ウム及び井化燐酸カルシウム置換説が学者の一致

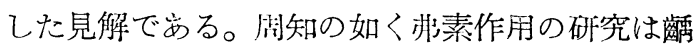
蝕予防と密接な関係に㟧るのでその原発部位とな る珐瑯質のみに従来の実験は限居されて来た。従 つて電子顕微鏡(以下電顕と略す)的観察に於ても 殆んぞの報告 ${ }^{10}$ は玹瑯質表面構造の変化に関する もので象牙質に就いての洲素作用の研究は殆んど 見当らない。
}

さきに岡田・三村11 は家躳に非素注射を行い歯 牙硬組織に変質層板の出現することを報告して居 るが，この方法に依れば確実に乘素化された部分 と然らざる部分との比較検討が極めて容易である からその形態学的举異を追究するには誠に好都合 である。象牙質横断面を何等の処理も施さずにそ の儘光学顕微鏡 (以下光顕々略す)的観察を行つて も一様な微粒像を呈するだけで基質, 象牙細管, 成長線及び灰化条などの微細構造は見られないの であるが，反之，弱酸で処理した後に鏡検すれば 脱扊度の装に依つて前記微細構造がかなり明膫に 現われて来る。この際㐫らかじめ非素注射を行つ 
そ家鬼に於ては，注射時刻に相当する象牙層板が 歯髄腔を囲む同心状河めて良好なコントラスト を呈するので容易に他の層板と識別することが出 来る（図 1，2 参澹）。之は弗素イオンの介入によ つて象牙質組成に変化を来たし耐酸性の強い石灰 化層が形成される為であらうと考皇るが，果して 歯牙表面に州素塗们を行つた場合之同様に肃化力 ルシウム或は弗化燐酸カルシウムの置撸が行われ て居るか否かに就いての確認はない。そこで斯る 非素变質層板の形態学的変化を電顐に低つて超俈 率下に検討し象牙質に於ける卯素作用の一端を解 明しようと試みた。

\section{実験方法}

実験動物には成熟家需を使用し，倠察のもつと も容易な下顎切歯鱼牙質の横断面を主と乙て用い た。電顕試料の作成は全て methylmethacrylate-aluminium 2 段レプリカ法 ${ }^{12}$ に低ることとし， shadowing 投射角度はこの場合小なる方が好ま しいので chrome を用いて5:1とした。なお 電顕写真は微絸像の検索を”容易にする為反転して いないので，従つて shadow 部は白く現われる。 家鬼を屠殺後，歯牙を抜去し，歯髄腔に対して直 角に切断した断面を砥不で可及的に滑沢にする。 研磨面は流水で洗桬した後充分に乾燥し, 以下通 法に従つて電顕試料を作成する。

1. 酸処理前の正常象牙質電顕像 対照となる 可き正常象牙質に就いての電顕像は未だ明膫にさ れて居ないので，正常家要雨牙を用いて前記方法 で観察を行つた。

2. 酸処理後の正常象牙質電顕像 正常象牙質 の酸に依る脱灰像も爾後の穾験には欠くことの出

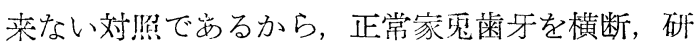
磨した後, $\mathrm{pH} 4$ の醋酸緩衝液中に 5 分間浸漬し て表面を軽く脱灰したものに就いて前記方法に從 つて試料を作成し電顕観察した。また実験 3 に於 ける正常層板は之之同一条件のものとみて新支光 ないのでそれに就いても観察を進めた。

3. 弗素に依る象牙質变質層板の電顕像 弗素 $0.5 \mathrm{mg} / \mathrm{kg}$ （弗化曹達を使用した）を 1 乃至 5 日
間隔に耳静脈内に注射乙最終注射より 7 日以後に 屠殺した家鬼の歯牙を横断，研磨後， $\mathrm{pH} 4$ の醋 酸緩衝液中に 5 分間浸漬し，光顕下で明らかに弗， 素変質層板の出現したものに就いて前記方法で電 顕試料を作成する。

電顕は北海道大学電顕研究室の JEM-4 型, HU 7 型, JEM-T 1 型及び 北海道大学結核研究所電 顕研究坴の JEM-4 型を使用させて戴いた。

\section{実験成績}

\section{1. 酸処理前の正常象牙質電:顕像}

象牙質断面は図 3 に見れらる如く種々なる凹陷 と微細な顆粒像から成つて居るが，全体的には均 等質であつて緻密な粒子様構造を呈する。その他 には光顕的に既知の組織像は殆んぞ認めないが,

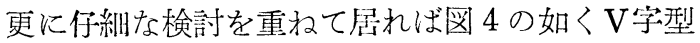
乃至半円型凹陷部の存在を確認することが出来 る。然も之等は互に組合わされて網状の連続像を 形成して居り，その大さは $0.2 \sim 0.5 \mu て ゙$ 粗密の 度合及び形態は部位的にかなりの変異も見られる が，推察するに基質部に出現する集団化した灰化

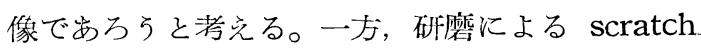
その他の二次的人工産物の出現することも㕍う市 る。

以上の像に就いては弗素注射家鬼象牙質に於て も全く同様で，特徴に玄可き構造は認めることが 出来なかつた。

2. 酸処理後の正常象牙質電顕像

石灰化の良好な部分と不充分なる部分とでは酸 による溶解度に等異が岕る訳であるが，弱酸処理， の場合には表面構造を損伤せずに種々なる微細像 を詳細に鑑別することが出来る。乞こで正常に発 育乙た像牙質断面を $\mathrm{pH} 4$ の醋酸緩衝液で 5 分間 処理した後の電顕像を酸処理前のそれに比較して みるに雨者は全く相違した像として確認された。

図 5 に見る如く粗整感が強くなり $0.01 \sim 0.03 \mu$ の大さをもつ顆粒像が㙰明に出現する。之は恐ら く象牙質の基本となる化灰粒子の脱灰像で岗万弓 と考劣る。他方, 酸処理前に僅かに見られた凹陷部 は灰化度の特に強い部分として橆易に確認され, 
然もその大さは $0.2 \sim 1.0 \mu$ となつて酸処理前の てれに較べて搪大して来る。従つて網様構造は益 々顕著となる。図6,7は chrome shadowing を行つたものでかなり微細な脱灰像まで詳細に現 われて居る。

以上の脱㕄像は更に大きな集団を形成するが， 図 8,9 の如く特に強調された像として見られる場 合と, 㱠んど確垫出来ない場合とが市るのは, 部位 的特街なのか或は横断方向の異によるのか朋確 でない。図に見られる如く直径 $5 \mu$ 前後の網様構 造であり且つその内部に前記脱灰像を包含し閶辺 部には灰化点と思われる像があること等から推察 するに，光顕写真 (図 2 参㷂)に見られる Interglobularnetz (球間緗)であろうと考市る。

然し乍ら像牙質脱灰面は必ずしも前記構造のみ を呈するものではなく, 部位に低つて或は試料の 異なることに依つて様々な像が見られる。図 10, 11 の如く層状構造の装程と之に直角な象牙細管 を思わせる構造から出来たものは，光顕的知識か らすれば密ろ理解し易い像の様で岗る。

他方，有機質に富む像牙細管は基質中に多数見 られる管であるが本实験ではかなり発見が困難で 市つた。歯牙の断面部位に低つては必ずしも一定 の形で出現するものではないが，図 $12 ， 13$ は略 々横断されたと思われる象牙絒管で 1 ～ $2 \mu$ の大 さのものである。之等の像は何れも Pease ${ }^{13)}$,

Bernick et al. ${ }^{14)}$ 及で Kennedy et al. ${ }^{15)}$ の報 告に類似して屈る。図 14 は之を更に拡大したも ので，40,000 以上の倍率像に於ては前記化死粒 子の確認が極めて䅉易で市る。

更にまた象牙質不灰化に重要な因子となる膠原 線維の観祭にはもつとも関心を抱いて局たが，本 実験方法では検䋕することが梌めて困難で市つ 心。Scott et al. ${ }^{16}$ の行つ心様に0.1 N HCl 位 の酸を使用して無機質を完全に溶解しなければそ の像は得られないだろう。Bernick et al. ${ }^{14)}$ も同 様に $10 \%$ 硝酸を使つて観祭して㞌る。図 15 は本 実験中に得られた膠原線維と思われる像で, 略々 $1.5 \mu$ の等間隔に並列乙て局る。各線維の㽬径は $0.05 \mu$ 前後を示し Scott et al. 及び Bernick et al.の報告に一致する。

3. 弗素による象牙質変質層板の電顕像 歯牙象牙質断面を醋酸緩衝液で処理すれば光顕 下では非素注射日に相当する日週期層を享易に区 別することが出来るのであるが，宁の構造を微紐 に検討することは图難である。テこで之を電顕下 に観察して以下の如き成績を得た。

図 16 は 3 日間連日州素注射を行つた場合で日 週期状に変質層板が配列して㢄る。層板境界部に 見られる線維像はこの部位が叫凹移行部に当るの で, aluminium 膜が圧し潰されて出来た兔で㐫 ららと推测される。

図 17 は chrome shadowing を行つたもので 2 日間隔に変質層板が見られる。図 18 は変質層 板の部分を拡大したものである。正常層板は極め て複雑な様相を呈して居るのに反して変質層板は 平滑で岕るから光顕下に見られる如く両者の脱灰 度の笵を識別出来る様にも思われるが，之を詳細 に観察すれば正常層板の像は不規则な線維様像で あつて aluminium 膜を平圤にする時に二次的 座物として出来た鄋で市万らと考党ることが出来 る。他方, 図 19 の如く蜜乃変質層板中に複雑な 像の出現孛ることも岕ることから推察すれば Scott et al. ${ }^{161}$ の報告して舒る種別不明の線維と 考光るのが妥当の様にも思われる。然しながら必 ずしも常にこの様な像を呈するのではなく図 20

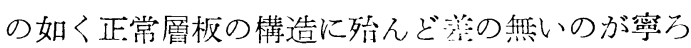
普通で幽る。従つて光顕下で明嘹に鑑別出来る試 料でも電顕像では鑑别困難な場合が屡々㟧る。前 者は脱灰された組織量の港に低つて生じた凹凹を 落下光線を利用して影を捕えたものであるが，後 者は脱灰面の最表層に垂直方向の電子線を投影し たものであるから層板全体の凹凸感は失われる訳 でめる。要するに電顕像では脱灰した表面構造の みを観祭して居ることになるので，その構造に管 異がないとすれば両層板の鑑则は極めて困難とな る。

他方また，図 21 に見られる如く変質層板中に

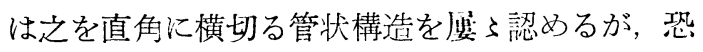

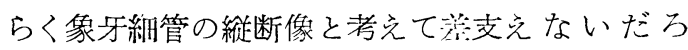


う。

更に図 22 の如く変質層板附近には直径 $2 \sim 4 \mu$ の多角形様構成物の出現することが時たま見られ るが，之は試料作成中に出来て人工産物なのか或 は弗素注射に因る石灰沈着の㩭乱を意味するもの かは断言の域でない。

弗素変質層板の電顕像は上述の如くで岗るが全 体的にみて正常層板の乞れと比較して榤したる相 違の無いことを知ることが出来た。

\section{総括並びに考按}

霜牙の電顕観察は Gerould ${ }^{17}$ 及る゙ Richard et al. ${ }^{17)}$ に低つて 10 数年前に開始され現在までには 既にかなりの業績が挙げられて居る ${ }^{13-20 j}$ 。從来行 われた研究の大半は菊蝕病変に関するもの 21 -34) 歯牙の弗素化に関するものに大別出来る。前者に 就いて蚝処では論外とするが後者に就いての実 験成果には橔めて貴重な報告が多い。即ち Gerould $^{25 i}$ は $4 \%$ 弗化曹達液中に 30 日間歯牙を浸溑 すれば珐瑯質中に弗化カルシウムの沈着が出現す ることを電顕及び電子迴折法から確認し, Scott \&Wyckoff ${ }^{26)}$ は電顕的には $2 \%$ 弗化曹達液中 7 日 間で弗化カルシウムの沈着を認めるが電子迴折で は僅か 3 分の浸漬で確認可能であり，然も斯る沈 着物は水洗を行觉ば容易に消失するものであると 報告して居る。また Fischer et al. ${ }^{27}{ }^{28)}$ は各種州 化物溶液の珐瑯質に対する作用を比較検討し，一 般に酸性液の方が燐酸カルシウムから州,化カルシ ウムに変化し易いことをX線及び電子迴折法から 解明した。更に松宫等 ${ }^{29-32)}$ は珄瑯質表面構造の詳 紐に就いて電顕的に検討を加光，Scott et al.の 実験と同じく弗化物塗布に低つて弗化カルシウム の沈着物を再確認して居る。弗素を雬牙に作用さ せた場合歯質の耐酸性が強化されることは既に閍 知の事実であり，之に加えて上記諸実験を考察す ればその成因となるのは歯牙組成の弜化カルシウ ム或は叛化燐酸カルシウム置捧であることは確実 と考えられる。

而して此の種実験は全て珠瑯質に関するものの 又で象牙質に就いての報告は殆んぞその例を見な

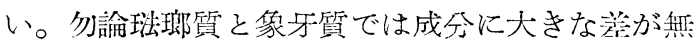
いので同一理論が成立する篦であるが，游素の介 入経路には明らかに等異があつて正常の場合には 血行路を介乙てのみ象牙質に到達されるものであ る。家鬼静脈内に州素を注射すればその一部は速 かに歯牙に移行し，その量が植めて微量で岗つて も注射時に形成される象牙質に形成障䨐を与える こと等に就いては篗洲 ${ }^{33)}$ がさきに詳細な実験報告 を行つて居る。然も珈素介入栠牙質は耐酸性のか なり強い層板で安つて, 恰も琌瑯質に於ける前記 諸実験と類似の結果を得ることが出来た。とこで 更に考察を進めて電顕的に之等の変化過程を追究 するに，先ず光顕的には全く見られない正常象牙 質断面の微細像が電顕的には明嘹に出現すること を知り，更に弱酸処理を行らことに依つてその 構造は一層明確に把握することが出来た。正常 像牙質には $0.2 \sim 1.0 \mu$ の扊化集団を見るが之は Pease $^{13)}$ 及び Bernick et al. ${ }^{14)}$ が脱灰空胞として 報告したものに相当すると思われる。然もとの基 体となる化灰粒子は $0.01 \sim 0.03 \mu$ の顆粒像と乙 て確認された。象牙細管, 膠原線維, 球間網なぞ の組織像は部位に依つて著明に出現するが，勿論 既往の光顕像と較べて同一の様相は呈しない。

以上の正常象牙質電顕像を対照として弗素介入 層板を検索するに，光顕下では極めて谷易に鑑別 出来たにも拘らず電顕下では乞の発見すら困難で あつた。時にはかなり㙰明な像として判別出来る ことも市つてその場合には酸に低る脱灰度の軽微 と思われる像を呈して局たが，全般的には本実験 に使用した 4,000 倍乃至 40,000 倍電顕像に於拜 る脱灰面構造は正常層板の乞れと比較して筀異を 認めなかつた。即ち前記諸報告に山る様な弗化物 沈着は変質層板中に出現して居ない。之は電顕倍 率の過少に低るのか或は酸に低る脱灰面に於ては その判別が不叮能のことなのか不明である。斯る 疑閏に就いては Scott \& Wyckoff ${ }^{26)}$ も同じ見解 を指摘して居る。彼等は珐瑯質に於ける実験で酸 処理後に弗素を作用させたものは弗化カルシウム の沈着を認めるが，この順序を逆にした場合には 耐酸性の増大は見られるが前記沈着物は確認出来 
ないと報告して居る。然し乍ら那素変質層板の耐 酸性が増大して居ることは光顕下に見られる脱灰 量が正常層板に比較して梌めて微量なことから確 実なのであるから，穴の成因となる可きものは両 層板の組成成分の変動にあることも文否定出来な い。本実験中に化灰粒子は $0.01 \sim 0.03 \mu$ の像と して確認されて居るが之は使用した電顕の解像限 度内ではあつたが比較検討して成分の鑑別を行ら には不充分で岗ることから侾えて，今後の研究に 於ては密万X線少至電子迴折法に低つて前記成分 の判定を行うのが望ましいことであろうと思う。

\section{結論}

1. 弗素静注によつて家鬼象牙質に出現する変 質層板の形態学的観祭を電顕を用いて行つた。

2. 象牙質断面に就いての電顕像を検討するに 弱酸処理後の脱灰面に於ては微細構造の観察も可 能なることを知つたので，之に依つて正常象牙質 電顕像の詳細を明らかにすることが出来た。

3. 弗素変質層板は耐酸性の特に強い部分とし て光顕的に確認されるが，之は脱灰量の养に依る もので表面構造の笙異に関係はない。他方，電顕 像では斯る層板の検出すら困難で岗つたが之は脱 灰後の表面構造が正常層板のそれと殆んど笙が無 い所以であろう。要するに酸処理後の弗素介入象 牙層板には従来報告された形化物の沈着は認める ことが出来ない。

4. 従つて斯る象牙層板の組成変化を追究する には電顕法に依るよりは迴折法を行うのが望まし いことである。

稿を終るに臨み終始御懇篤なる御指導と御校閲を賜 つた恩師真崎教授に満腔の 謝意を搨げ，電子顕微鏡使 用に当り御便宜並びに御助言を賜つた電子顕微鏡研究 室の方々に感謝する。

\section{交献}

1) Volker, J. F. : Effect of fluorine on solubility of enamel and dentin, Proc. Soc. Exper. Biol. \& Med. $42:$ 725, 1939.

2) Volker, J. F.: Solubility of fluorosed enamel and dentin, Proc, Soc. Exper. Biol. \&
Med. $43: 643,1940$.

3) Muhler, J. C. et al. : Solubility of enamel protected by sodium fluoride and other compounds, J. D. Res. 26 : 119, 1947.

4) Zipkin, I. : Inhibitory effect of fluoride on teeth decalcification by citrate and lactate in vivo, J. D. Res. $28: 151,1949$.

5) Manly, R. S. : Substances capable of decreasing the acid solubility of tooth enamel, J. D. Res. $28: 160,1949$.

6) Rathje, W.: The formation of hydroxyfluor apatite in tooth enamel under influence of drinking water containing fluoride, J. D. Res. $31: 761,1952$.

7) Fischer,R. B. \& Muhler, J. C. : Relationship between $\mathrm{pH}$, age, and concentration of solutions of stannous fluoride and sodium fluoride in decreasing enamel solubility and affecting the uptake of fluorine, J. D. Res. $31: 756: 1952$.

8) Massler, M. : Effect of various fluoride salts in inhibiting acid action on intact enamel, J. D. Res. $32: 628$, Meeting No. 171 , 1953.

9) Muhler, J. C. et al. : Studies on stannous: fluoride and other fluoride in relation to the solubility of enamel in acid and the prevention of experimental dental caries, J. D. Res. 33 : 33, 1954.

10) Wyckoff, R. W. G.: Electron microscopy, London, 1949, p. 105.

11）岡田正弘, 三村二 : 硬組織の生理及び 菜理（第. 28 報)，日薬理誌. $48: 199 \S ， 1952$.

12）䈎川久吾: 電子顕微鏡, 東京, 昭 26,182 頁.

13) Pease, D. C.: Electron misoscopy of sec-tioned teeth, Anat. Rec. $110:$ 539, 1951.

14) Bernick, S. et al.: Electron microscopy of enamel and dentin, J. A. D. A. $45: 689$, 1952.

15) Kennedy, J. J. et al. : The ultramicroscopic structure of enamel and dentin, J. A. D. A. $46: 423,1953$.

16) Scott, D. B. \& Wyckoff, R. W. G. : Electron microscopy of human dentin, J. D. Res. 29 : 556, 1950.

17) Gerould, C. H. : Ultramicrostructures of the human tooth as revealed by the electron microscope, J. D. Res. 23 : 239, 1944.

18) Richard, A. C. \& Thomassen, L. : Microstructure of tooth surfaces as revealed by the electron microscope, J. A. D. A. 31 : $772,1944$. 


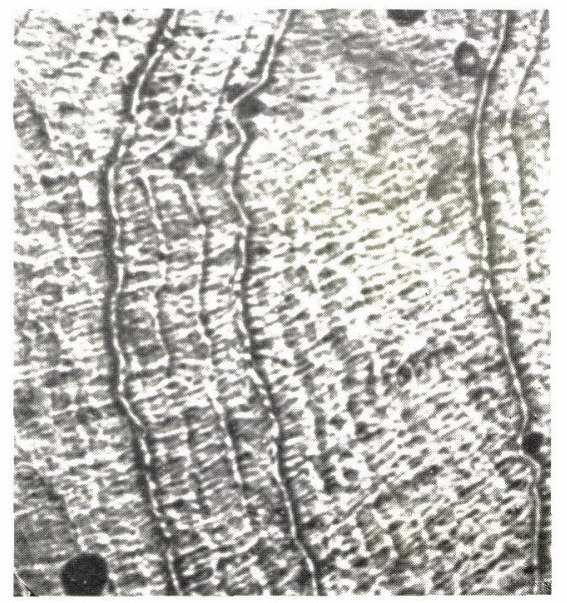

成 1 (光 顕)
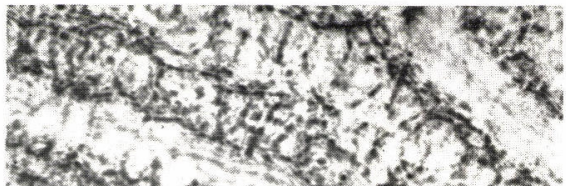

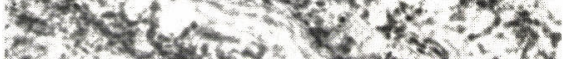

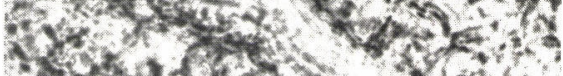

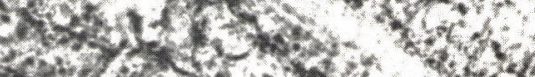

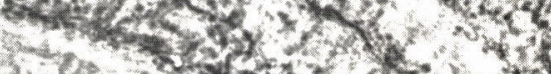

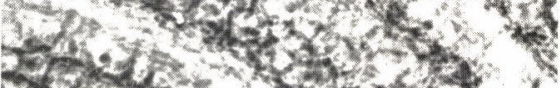

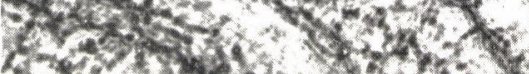

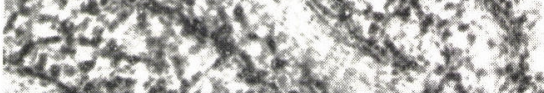

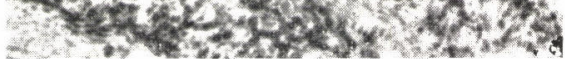
成 2 (光 非)

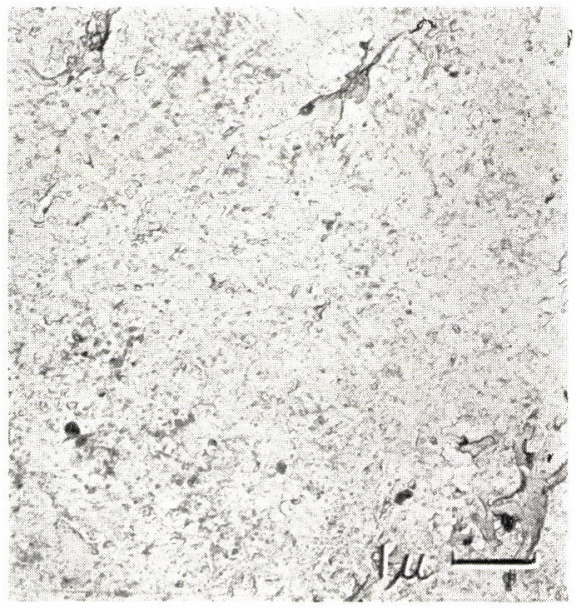

[ 3

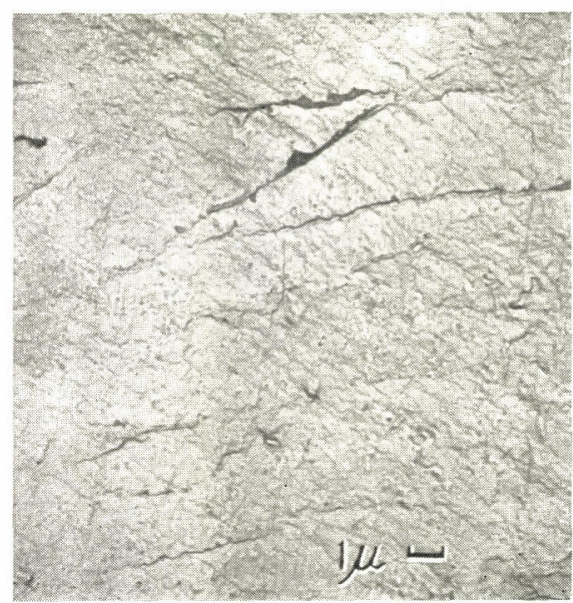

an $x+3$

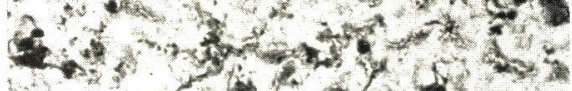

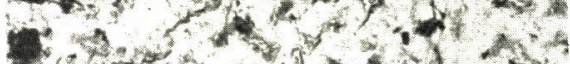

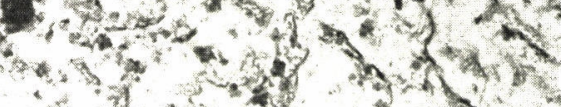

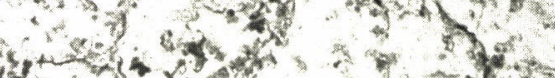

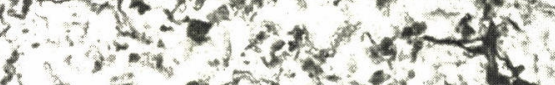

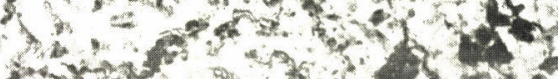

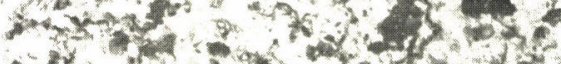

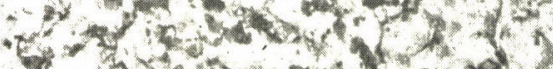

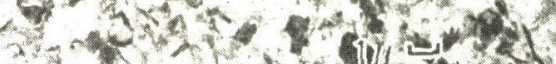

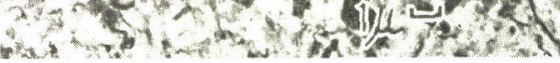
成 5

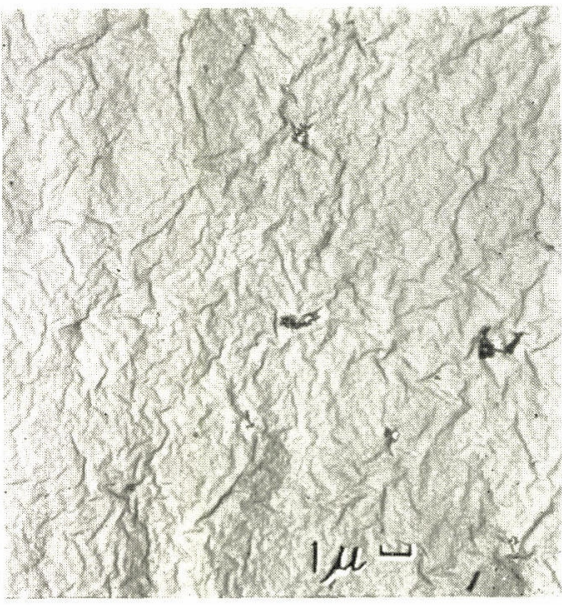

図 6 

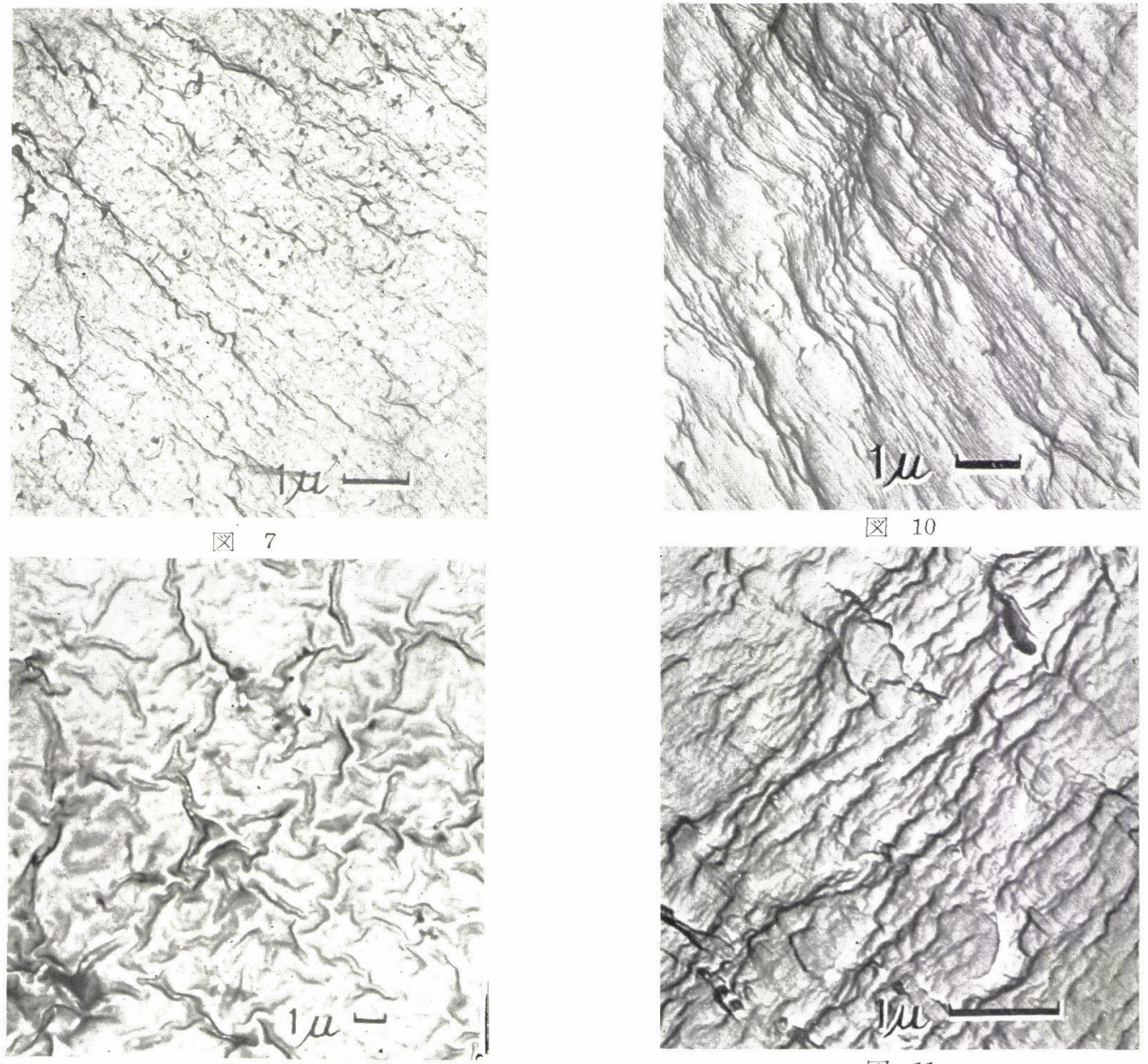

成 8

成 11
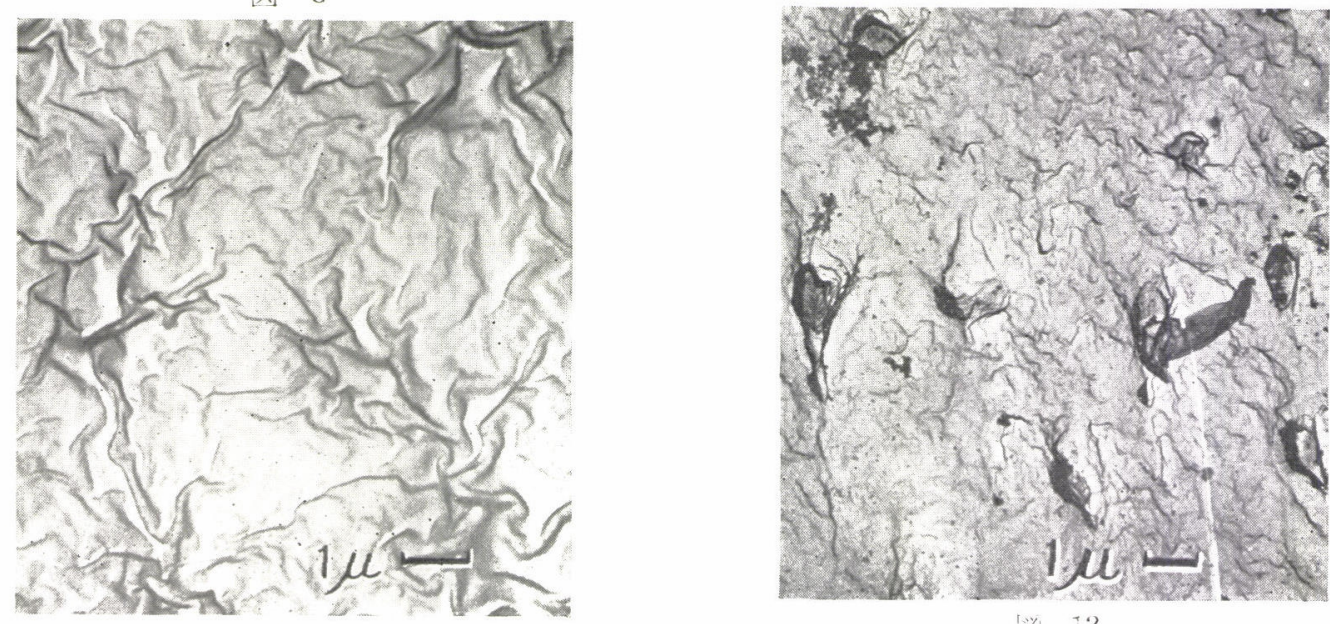


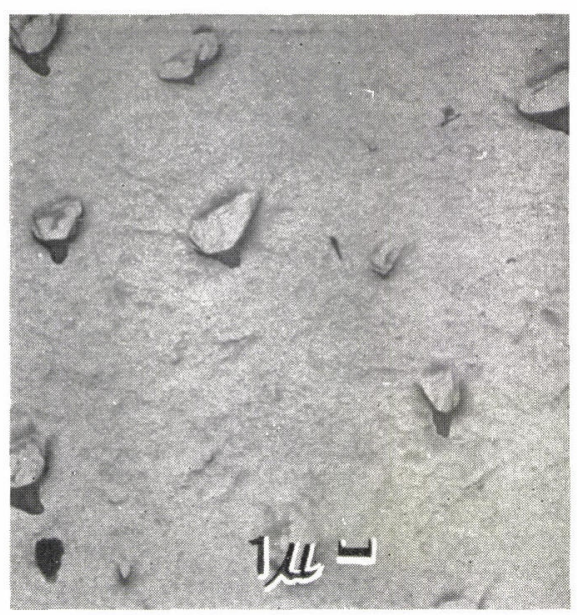

図 13

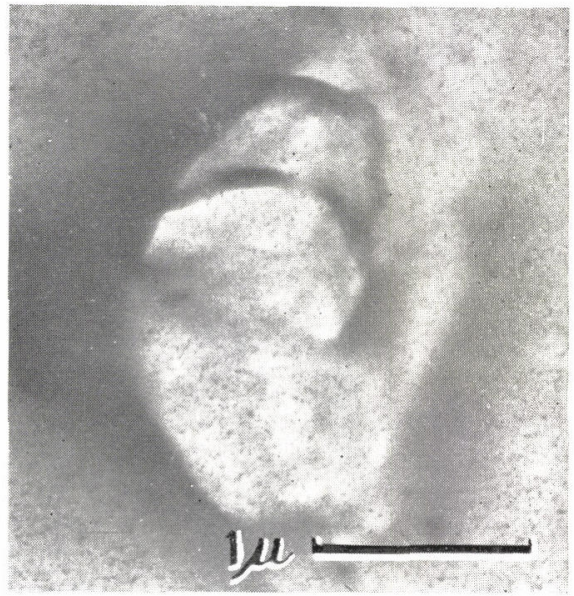

図 14

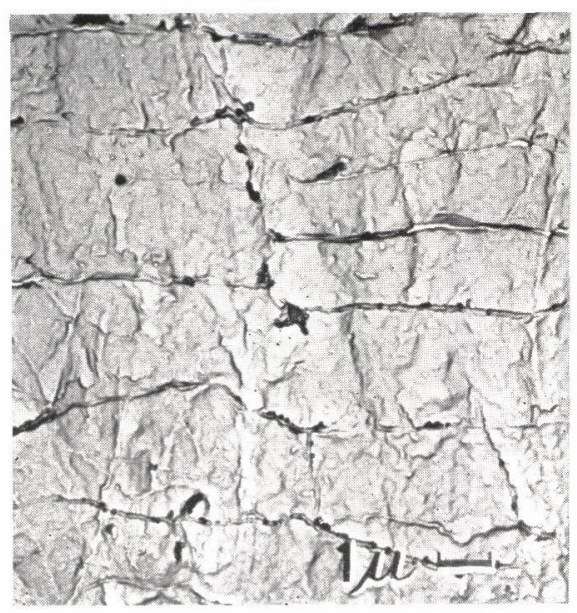

[为] 15
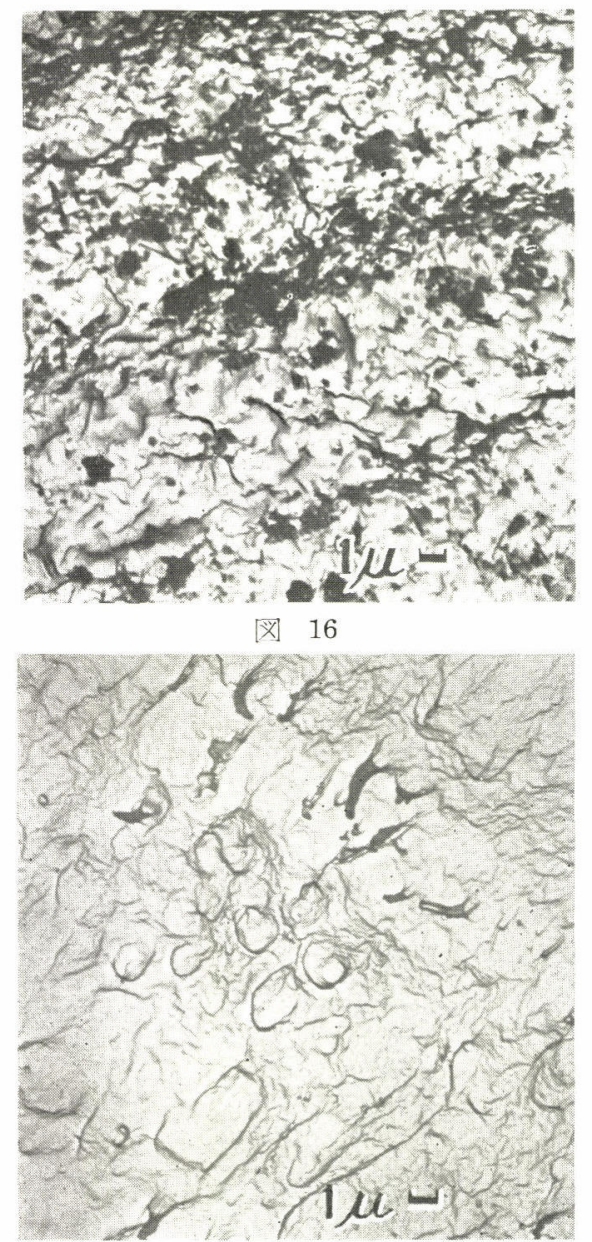

図 17

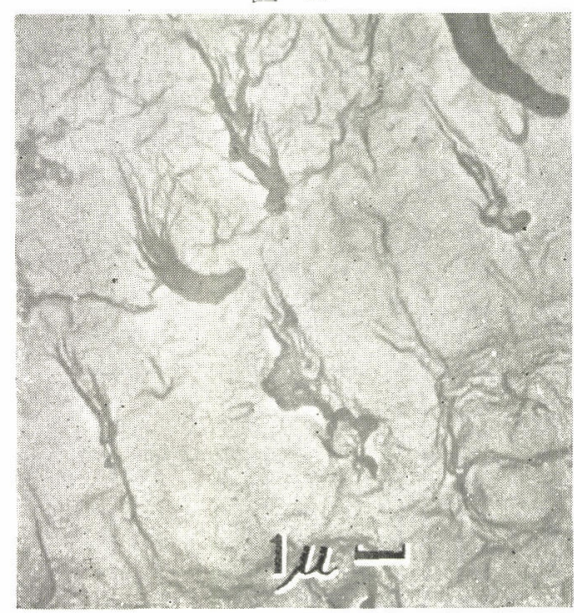

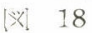




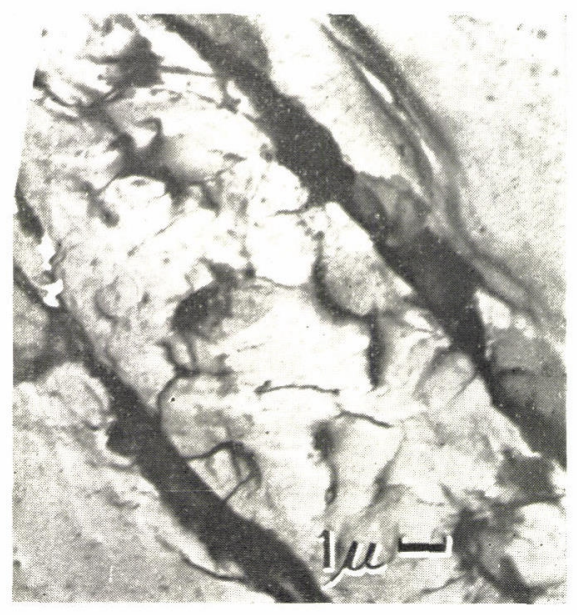

网 19

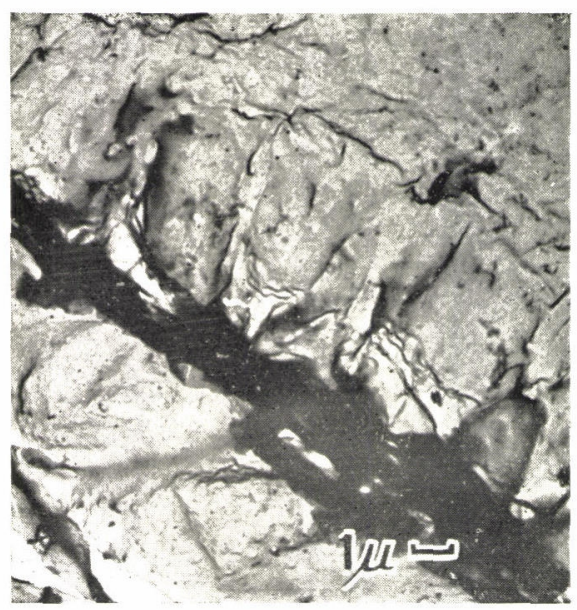

図 20

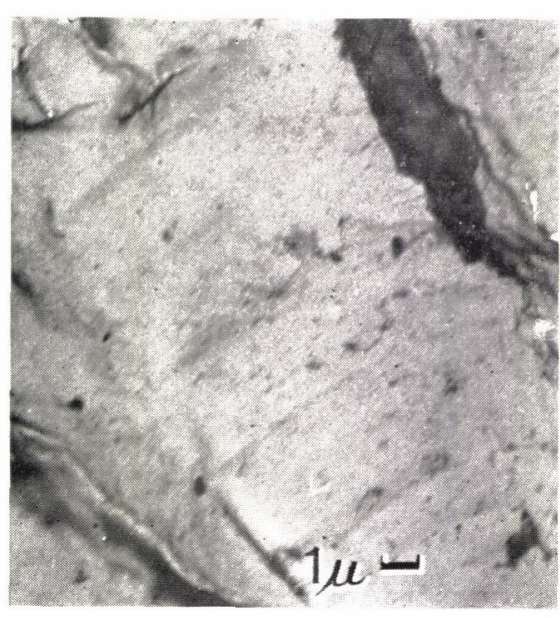

図 21

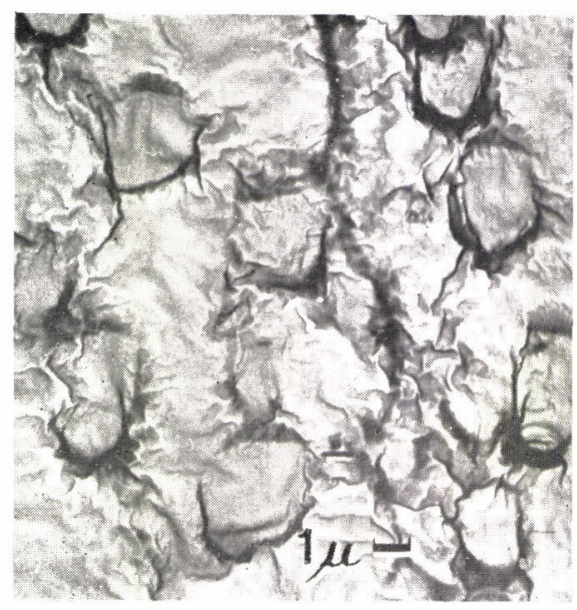

図 22 
19) Scott, D. B. et al. : Studies of tooth surface structure by optical and electron microscopy, J. A. D. A. 39 : 275, 1949.

20) Albright, J. T. et al. : Demineralization and dehydration of dental tissues for electron microscopy, J. D. Res. 31 : 455, Meeting No. 64, 1952.

21) Scott, D. B. \& Albright, J. T. : Electron microscopy of carious enamel and dentin, J. D. Res. 32 : 628, Meeting No. 120, 1953.

22) Bernick, S. et al. : Electron microscopy of carious dentin, J. D. Res. 33 : 20, 1954.

23) Lenz, H.: Elektronenmikroskopischer Nachweis der Dentinveränderungen durch Karies, Dtsch. Zahn-Mund-Kieferhlk. 22 : 24, 1955.

24) Helmcke, J. G. : Elektronenmikroskopische Strukturuntersuchungen an gesunden und kranken Zähnen, DDZ. 15 : 1461, 1955.

25) Gerould, C. H. : Electron microscope study of the mechanism of fluorine deposition in tooth, J. D. Res. $24: 223,1945$.

26) Scott, D. B. \& Wyckoff, R. W. G.: Studies of the action of sodium fluoride on human enamel by electron microscopy and electron diffraction, Pub. Health Rep. 65 : 43, 1950.

27) Fischer, R. B. \& Muhler, J. C. : The effect of sodium fluoride upon the surface structure of powdered dental enamel, J. D. Res. 31 : 751, 1952.

28) Fischer, R. B.\& Muhler, J. C. : Effects of several fluoride reagents on the surface structure of powdered dental enamel, J. D. Res. 33 : 50, 1954.

29）松宮誠一，出熊庄三郎，士倉秀次：来牙龄蝕と 其予防に関する電子顕微鏡的研究 ( I ), 菌科学 報 $50: 61,91 ， 1950$.

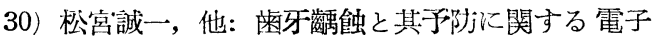
显頁微鏡的研究 (2), 菌科学報 $52: 121,173$, 1952.

31）松管”誠一，田熊庄三郎：超薄切片による料牙硬 組織の電子顕微鏡像, 最新医学 $9:$ 1167, 1954.

32) Takuma, S.: The electron microscopy of the enamel surface of teeth under various abnormal conditions, J. D. Res. 34 : 152, 1955.

33）等畐賢三，弗素の茵牙に対する作们に就ての穾 験的石开究, 口胵病学会雑誌 $23: 13,1956$. 